\title{
Is it appropriate to support the farmers for adopting conservation agriculture? Economic and environmental impact assessment
}

\author{
Antonio Troccoli, Carmen Maddaluno, Massimo Mucci, Mario Russo, Michele Rinaldi \\ Cereal Research Centre, Council for Agricultural Research and Economics, Foggia, Italy
}

\begin{abstract}
Conservation agriculture (CA) in the last decades has been spread in several parts of the world, especially in South and North America and Australia. In Italy, however, its adoption is often restrained by the risk to have a reduction in crop production in the early years of transition from conventional (CT) to CA.

To quantify sufficient financial support to promote no-tillage and $\mathrm{CA}$, a mini-review about main effects of $\mathrm{CA}$ was conducted. The effect on crop yield, soil fertility - especially as it is influenced by the chemical, physical and microbiological factors - on soil compaction, the economic balance of the farm and the cost of equipment for direct seeding, the influence of environment on soil erosion, water retention, emissions of greenhouse gases, and carbon sequestration are briefly treated. The paper reports findings from national and international scientific literature and some results from long-term experiments conducted in Southern Italy. The main conclusions are about the reduction of yield in the first years of transition from CT to CA (from -5 to $10 \%$ ), an improvement of soil fertility (soil organic carbon increases in the upper layers), reduction of management cost (less machinery operations), improvement of soil $\mathrm{C}$ sequestration (in specific conditions), a reduction of greenhouse gases emission and soil erosion risk.

The paper provides the scientific basis in order to justify and quan-
\end{abstract}

Correspondence: Antonio Troccoli, Cereal Research Centre, Council for Agricultural Research and Economics, S.S. 673 km 25+200, 71122 Foggia, Italy.

E-mail: antonio.troccoli@entecra.it

Key words: Conservation agriculture; tillage; economic support; soil organic carbon; durum wheat.

Acknowledgements: this research was carried out under the Basilicata PSRFEASR Regional Call Misura 124, Research Project BIO-TILLAGE, Prov. Conc. N. 124-AC/2014/02 (Coord. Prof. M. Perniola).

Conference presentation: SIA XLIII Congress, Pisa, 2014.

Received for publication: 30 January 2015.

Revision received: 11 May 2015.

Accepted for publication: 11 May 2015.

(C) Copyright A. Troccoli et al., 2015

Licensee PAGEPress, Italy

Italian Journal of Agronomy 2015; 10:661

doi:10.4081/ija.2015.661

This article is distributed under the terms of the Creative Commons Attribution Noncommercial License (by-nc 3.0) which permits any noncommercial use, distribution, and reproduction in any medium, provided the original author(s) and source are credited. tify the amount to be paid to the farmers who decide to adopt the model of CA, oriented to protect the agro-ecosystem and to promote the principle of subsidiarity.

Finally, a proposal of public subsidy in cash and for machinery purchase has been described.

\section{Introduction}

Conservation agriculture (CA) is an approach to managing agroecosystems for improved and sustained productivity, increased profits and food security while preserving and enhancing the resource base and the environment. CA is characterised by three linked principles, namely: i) continuous minimum mechanical soil disturbance; ii) permanent organic soil cover; iii) diversification of crop species grown in sequences andor associations (FA0, 2011).

The CA management is nowadays used, especially for cereal sowing, over 155 millions of hectares all over the world (FAO, 2015), with a large diffusion in South and North America and Australia. In Italy the extend of CA is limited to about 380 thousands hectares, but it is often hampered by various aspects related to a farmers' low risk-taker attitude, a limited knowledge of the techniques of CA and a national agricultural policy which is not inclined to give financial support to farmers in the renewal of agricultural machinery. It is important to clarify that it is misleading to have short-term results with the adoption of CA because its effects are visibly expected after a medium or long period of activity.

The question we want to face is: why the community should support the CA adoption, if the farmer has already a reduced production cost and if CA generally leads to an improvement of soil fertility (absence of soil tillage; improvement of soil organic content, structure and microbial activity)?

This paper aims to highlight the reasons because it should be fundamental a financial support for the expansion of conservation techniques. We want assess and discuss the main agronomic, economic and environmental aspects that the stakeholders should consider during the decision process if support or not the adoption of CA and at which amount.

\section{Materials and methods}

Data from national and international literature (Pisante, 2008; Morris et al., 2010; Palm et al., 2014; Pittelkow et al., 2015) were considered to assess the main agronomic, environmental and economic aspects that can be helpful for stakeholders in the decision-making process to support the CA adoption. When the case occurs also the experimental data obtained in the Council for Agricultural Research and Economics (CREA)-Cereal Research Centre (CER) of Foggia from 
long-term experiments on durum wheat (De Vita et al., 2007; Troccoli et al., 2007, 2009a, 2009b, 2014; Colecchia et al., 2015) were shown and compared with those of the literature.

\section{Results and discussion}

\section{Agronomic aspects}

Are really the yields reduced with the conservation agriculture adoption?

Pittelkow et al. (2015) performed a meta-analysis with more than 5400 paired data from literature on 610 worldwide experiments on CA: they concluded that no-till (NT) yields were about 5-10\% less than conventional tillage (CT). This response is variable and under certain conditions NT can produce equivalent or greater yields than CT. When NT is combined with the other two CA principles, such as residue retention and crop rotation, its negative impacts are minimised. Indeed, CA resulted in increasing rainfed crop productivity especially in dry climates, suggesting that it may become an important climate-change adaptation strategy for ever-drier regions of the world.

Van de Putte et al. (2010) showed as in 47 European studies the adoption of CA decreased the yield from 4.5 to $8.5 \%$, also in drier climatic conditions. On the contrary, in Southern Italy, Sicily, Ruisi et al. (2014) reviewed 20 years of experimental data and evaluated as only in the dry and less productive years the NT was more yielding than CT (Figure 1). Our data (Troccoli et al., 2014) showed that in fifteen years of monoculture of durum wheat grown in southern Italy $\left(41^{\circ} 27^{\prime} \mathrm{N}\right.$, $15^{\circ} 30^{\prime} \mathrm{E}$, altitude $79 \mathrm{~m}$; Foggia, Apulia region), and despite the great and significant seasonal variability (year: $F_{(14,15)}$ test $=14.164$, $\mathrm{P}$ value $=$ 0.0001 ) found between NT (range 1.29-3.81 tha-1) and CT (range 0.76$\left.4.54 \mathrm{t} \mathrm{ha}^{-1}\right)$, the overall grain yield of NT $\left(2.61 \mathrm{t} \mathrm{ha}^{-1}\right)$ was only lower than $1.5 \%$, but not significantly, compared to CT $\left(2.65 \mathrm{t} \mathrm{ha}^{-1}\right)$ (Figure 2). In 2007 e 2008 the yields difference in favour of CT were $3.5 \% \mathrm{e}$ $3.2 \%$, respectively (Troccoli et al., 2007; Troccoli et al., 2009b). Conversely, the difference between the yields of grain of NT and CT cumulated at the $15^{\text {th }}$ year showed an average balance positive by about $5 \%$ and a net income cumulative average of $71 € \mathrm{ha}^{-1}$ in favour of NT (Troccoli et al., 2014). The experiment was carried out on a clay-loam

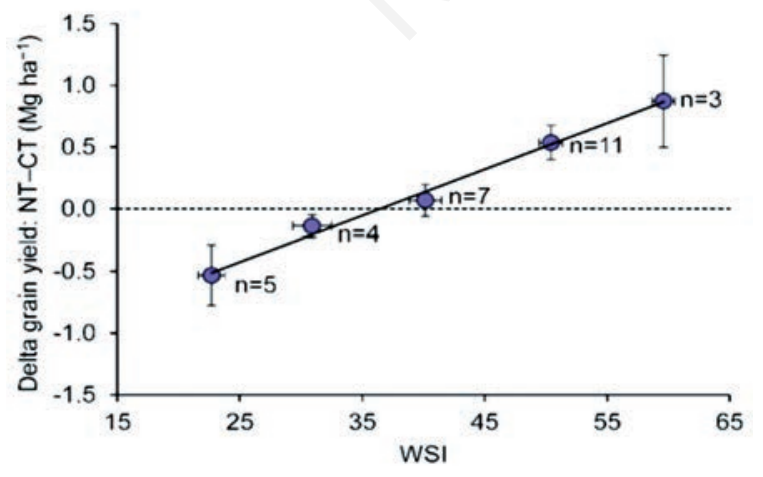

Figure 1. Relationships between water stress index (WSI=1$\Sigma$ ETact $/ \Sigma$ ETpot) and the differences in the grain yield of wheat between no-tillage (NT) and conventional tillage (CT). Data grouped by WSI values into five classes; $n=$ number of data of each class. Horizontal and vertical bars indicate the standard errors of each mean value (from Ruisi et al., 2014). soil (Vertisol), classified as Typic Calcixerept (Soil Survey Staff, 1999). Average annual temperature is $15.8^{\circ} \mathrm{C}\left(10.2 / 21.4^{\circ} \mathrm{C}\right)$, and mean annual rainfall is $534 \mathrm{~mm}$ (period 1955-2010). Two tillage systems were compared: CT with mouldboard ploughing at $40 \mathrm{~cm}$, and NT, with straw removed in the two plots of 0.6 ha each.

Colecchia et al. (2015) stated as in the first 2 years of conversion from CT to NT the durum wheat yield reduced about $23 \%$, especially in wet years, but with no influence on grain quality.

Most likely these controversial results can be explained by taking into account, on the one hand, the different environmental conditions (soil structure, fertility level, rainfall and evapotranspiration regimes) and, second, the benchmark of the soil at the time of transition from conventional agriculture to the permanent state of CA [i.e, before switching to CA) soil hard pan must be absolutely broken, the stone surface should be removed, and so on]. In addition, the variability found in yields response between the two agricultural systems could be due to the similarity in the experimental management applied to CT and CA (Derpsch et al., 2014) that should differ, besides the soil tillage, even for fertilising, seed quantity, crop rotation, and weed control. In the future, since NT and CT systems differ in all these aspects, the most appropriate agronomic practices to optimise yields in each environment should be applied.

How conservation agriculture management affects the soil fertility

There is clear evidence that topsoil organic matter increases with CA and, consequently, other soil properties and processes that reduce erosion and runoff and increase underground water quality. Soil moisture retention can be higher with CA, resulting in higher and more stable yields during dry seasons but the amounts of residues and soil organic matter (SOM) levels required to attain higher soil moisture content is still not known. Biodiversity is higher in CA compared to conventional practices. Soil organic matter is an integrator of several soil functions and as such is a key component of soil quality and the delivery of many ecosystem services (Palm et al., 2014). The CA practices of no-tillage and residue retention are key-points to maintain or increase SOM in the topsoil which in turn provides energy and substrate for soil biota activities and their contributions to soil structure and nutrient cycling, as well as many other soil processes and ecosystem service (Brussaard, 2012). In general, CA practices increase SOM and other soil biological properties. These effects are, however, generally confined to the topmost soil layer (up to $10 \mathrm{~cm}$ in

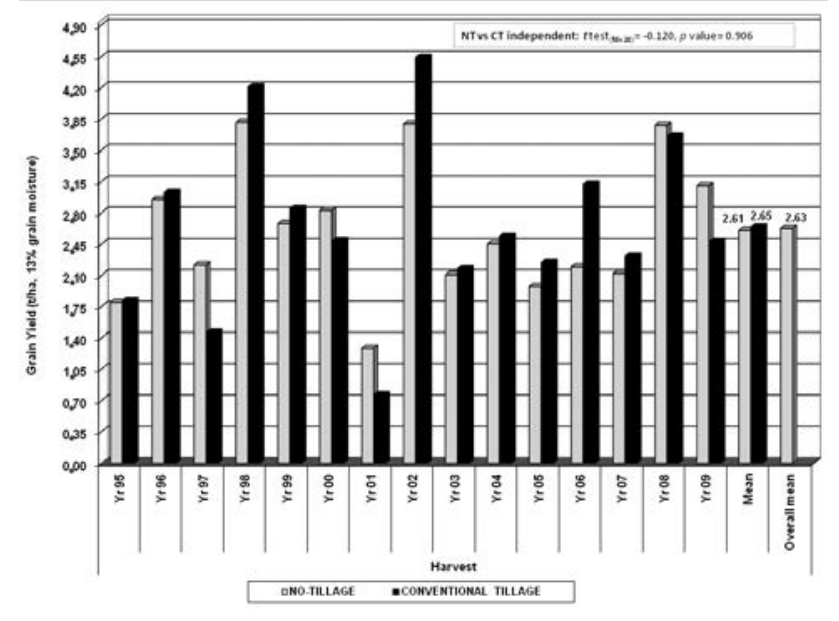

Figure 2. No-tillage (NT) and conventional tillage (CT) grain yields trend of durum wheat continuous crop grown in southern Italy (Foggia, $41^{\circ} 27^{\prime} 36.720^{\prime \prime} \mathrm{N}, 15^{\circ} 30^{\prime} 03.494^{\prime \prime} \mathrm{E}$; $90 \mathrm{~m}$ a.s.l.) during 1995-2009 period (from Troccoli et al., 2014). 
depth) but are often not evident going beyond $15 \mathrm{~cm}$ (Verhulst et al., 2010; Bissett et al., 2013). These differences in SOM concentrations and distribution combined with lack of soil disturbance and crop rotations affect the abundance, diversity, community composition, vertical distribution within the soil profile, and activities of soil biota. These effects have concomitant changes in decomposition, nutrient cycling, bioturbation, soil aggregate stability, and other soil ecosystem services (Bignell et al., 2005). In fact, Fornasier et al. (2012) found in 2011 in the long-term CA experiment at CREA-CER (Foggia) that the values of esterase, total organic carbon (TOC), total nitrogen (N) and DNA were from 30 to $50 \%$ higher than conventional, as well as were from 70 to $90 \%$ higher for arylsulfatase, $\beta$-glucosidase, leucine-aminopeptidase, alkaline phosphatase, chitinase in NT than in CT system. In addition, these differences were mostly driven by an accumulation in the first $5 \mathrm{~cm}$ of NT plots, where the concentrations increased greatly from $49 \%$ of TOC up to $400 \%$ of $\beta$-glucosidase respect to the beneath layer $5-30 \mathrm{~cm}$.

How conservation agriculture management affects the soil physical features

Bulk density (BD) is an indicator of soil compaction. It reflects the soil's ability to give for structural support, water and solute movement and soil aeration. A system that uses cover crops, crop residues, notillage, and/or reduced tillage in theory it is expected to increase SOM and to have a low disturbance and a reduction of the bulk density. Also for this parameter the evidences are conflicting. Some studies have reported a drastic increase in bulk density with no-till compared to mouldboard plowing of a clay loam soil (Griffith et al., 1977; Gantzer and Blacke, 1978). Blevins et al. (1983) found similar bulk density values with CT and NT systems. But an increase in the bulk density is not necessarily detrimental to crop growth, because at certain limits this increase may contribute to soil water storage and load support ability when trafficked with machines (Reichert et al., 2009). In fact, although the ploughpan layer from the previous CT remained intact and compacted under a long-term no-tillage (Håkansson, 2005), the functioning of soil pores can improve if the majority of the total annual wheel track area is limited to restricted areas allowing the remaining no-till area to have a lower load (Reichert et al., 2003; Horn, 2004). Typically, a layer soil from about 7 to $15-20 \mathrm{~cm}$ with characteristic of high bulk density, low porosity, and high mechanical resistance could be referred to as a no-till pan. The aforementioned layer underlies an upper layer (from 0 to about $7 \mathrm{~cm}$ ) of reduced compaction due to rearrangement of soil par-

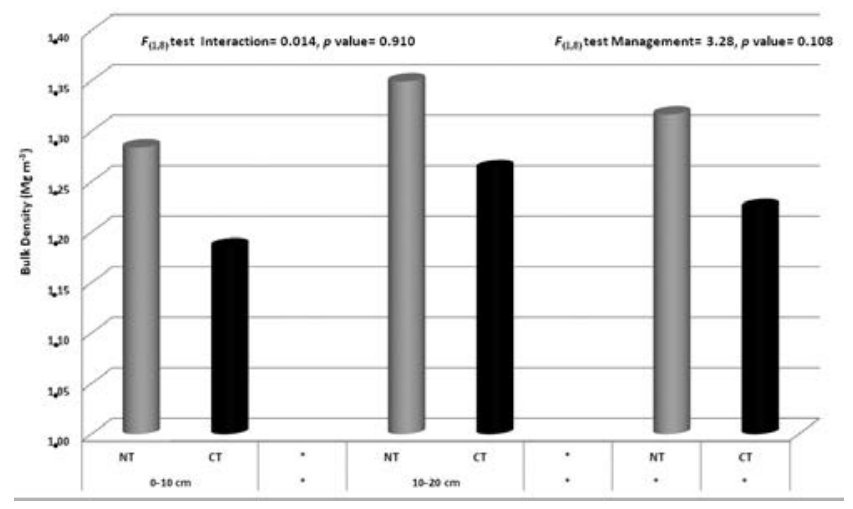

Figure 3. Soil bulk density measured before durum wheat sowing at two depth levels in the no-tillage (NT) and conventional tillage (CT) systems, at the end of the 1995-2009 period at the Cereal Research Centre-Council for Agricultural Research and Economics of Foggia. ticles and aggregates by various processes (Horn, 2004; Håkansson, 2005), such as biological processes, which are most intense near the surface mulch layer (Reichert et al., 2003), and action of coulters and shanks of no-till seeders and planters coulters (Genro Jr., 2002).

The results obtained by the CREA-CER in 2009 agreed with the evidences of the literature. Before durum wheat sowing, the values of bulk density measured in the NT were higher, but not significant, compared to CT. In both systems, the bulk density of the soil measured at two levels of depth were not significant, even if the shallow layer $(0-10 \mathrm{~cm})$ showed BD values that were lower than the deepest level $(10-20 \mathrm{~cm})$ (Figure 3).

\section{How conservation agriculture management affects the soil compaction}

The soil penetration resistance is a parameter, measured by a cone penetrometer and also named as soil cone index (CI), related to bulk density and is widely used to assess soil loosening or compaction in tillage studies. Carter (1988) measured mechanical resistance in a tillage study and found that mouldboard plowing produced more soil loosening than chisel plowing in a loam to sandy loam soil. Kacemi $e t$ al. (1992) found that CI values from the 0 to $10 \mathrm{~cm}$, and 40 to $50 \mathrm{~cm}$ depths were not significant different among tillage methods, while between the 5 and $35 \mathrm{~cm}$ soil depths the differences were highly significant. In addition, the mouldboard plow maintained consistently lower CI whereas no tillage had consistently higher over the 0 to $50 \mathrm{~cm}$ depth. Other studies proved that $\mathrm{CI}$ values were usually greater in no-tillage systems than in conventional tillage systems, especially in the top layer (Chen et al., 2004; Bueno et al., 2006). Soil cone index also varies within the soil depth profile. Lower CI values are associated with a tilled layer near the soil surface, while higher CI values are associated with a compact soil layer below the tilled layer (Chen and Tessier, 1997; Doan et al., 2005). CI is also affected by the soil moisture (Franzen et al., 1994) and higher values were found associated with drier soils (Tekeste et al., 2008). A field trial carried out in southern Italy (Campania region), on a clay soil at the $10^{\text {th }}$ year of NT and in two stages of crop growth (March: jointing stage; and June: maturity), was performed using an ultrasonic Rimik CP20 cone penetrometer (Agridry Rimik Pty Ltd., Toowoomba, Australia) with the following settings: 12 $\mathrm{mm}$ cone diameter, $0.60 \mathrm{~m}$ max depth, $25 \mathrm{~mm}$ measurement interval, $60 \mathrm{~kg}$ max load (about $4714 \mathrm{kPa}$ ), $2 \mathrm{~m} \mathrm{~min}^{-1}$ max speed. Generally, the results showed that usually NT had a CI slightly higher than CT, except in dry conditions (June) and in the shallow soil layer (0-0.15 m) when NT soil appeared to be less compact than CT (Figure 4).

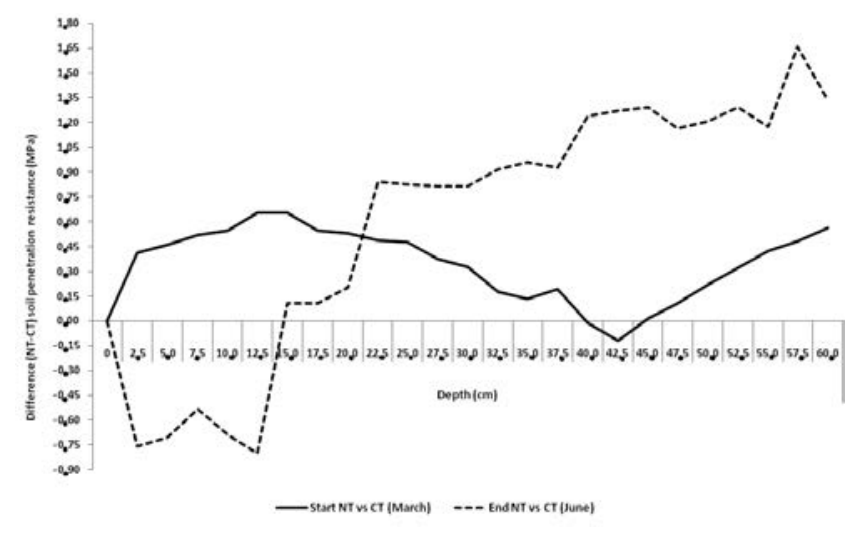

Figure 4. Trend of soil cone index values, expressed as difference between no-tillage (NT) and conventional tillage (CT), in March (jointing stage) and June (maturity) for a durum wheat crop grown in southern Italy (Campania region) during the 2013/14 growing season $\left(10^{\text {th }}\right.$ year of NT). 


\section{Economic aspects}

How conservation agriculture management affects the production costs

Farmers from both developing and developed countries have to cope with several production constraints for achieving a sustainable and costeffective grain production. In terms of economical return and profitability, minimum or no-tillage may substantially reduce crop production costs, as mechanised tillage is a rather costly technique including fuel, labour and machinery costs. In the grain production systems, relative benefits of $\mathrm{CA}$ depend on the difference between the costs of soil tillage vs. the cost of chemical herbicides applied before sowing.

In CA systems, the use of machinery is characterised by lower farm power requirements and reduced number of passes across the field if compared to conventional systems. This translates into lower rates of soil carbon oxidation, low-power tractors and longer tractor life, reduced working time, hence slower depreciation rates of equipment and less fuel consumption per unit area per unit of output (FAO, 2001). Nowadays, total herbicides, such as glyphosate, are relatively cheap, stimulating their wide use by CA farmers (Landers et al., 2008). In Table 1 is summarised the relative carbon cost of CA compared to conventional system (Corsi $e t$ al., 2012), while Table 2 shows the average twenty-year (1995-2014) of only the differential costs of the two soil management systems collected at CREA-CER of Foggia in order to evaluate the economic potential of NT vs CT. The differential costs between models leads to an average yearly economic benefit of $77 € \mathrm{ha}^{-1}$ for the farms that would adopt the CA model. In the Figure 5 it is possible to see the trend of total and differential costs for NT and CT systems during 1995-2014. From a socioeconomic perspective, Scopel et al. (2012) stated that conservation agriculture systems have been shown to be generally profitable if their adoption translates in lower production costs, starting with the quasi-suppression of the land preparation costs, coupled with the maintenance or an increase in grain yields. Under appropriate management, i.e., without problems of crop establishment, weed and/or pest control, the labour requirements and costs may decline. Usually, for both resource use efficiency and socioeconomical results, the situation becomes more favourable after some years of conservation agriculture application when systems stabilise.

How conservation agriculture management affects the machinery investments

No-tillage systems and mature CA optimised over a period of time are oriented, form a mechanical point of view, towards minimum disturbance no-till furrow openers, such as double-disk, cross slot or star-wheel type tools, which also facilitate weed control management. Equipment for mechanical surface weed management includes slashers, cutters or crimper-rollers while sprayers remain the main tool for herbicide application. Another important aspect is the treatment of the residues. The most important tools specific of CA, also used for residue, cover crop and weed management are knife roller, crop crimper and vegetation crusher.
Due to the potential benefits of CA systems, the availability and accessibility of equipment and machinery for CA are often the strongest impediments for the successful introduction and up scaling of CA. For example, as can be seen in Table 3 a direct seeder has a price that is much higher than a seed drill pneumatic or mechanical. Therefore, a policy that really wants to preserve the environment absolutely cannot prescind from a suitable policy of investments or to facilitate access to money to farmers or directly in supporting the cost of equipment and machinery to replace the old machine park inappropriate for CA management.

\section{Environmental aspects}

\section{Soil erosion and water retention}

Minimum, reduced or no-tillage, as well as the surface covered by residues, directly reduce erosion by minimising the time that the soil is bare and exposed to wind, rainfall and runoff. CA and NT can reduce wind erosion due to the larger proportion of dry aggregates, less wind erodible fraction and greater crop residue cover of the soil surface (Singh et al., 2012). CA can also indirectly reduce erosion by water through the effects on soil properties and processes that increase water infiltration and reduce runoff.

NT management generally increases bulk density of the topsoil, reduces total soil porosity, and even hydraulic conductivity compared to CT systems. Although these changes should lead to lower rates of water infiltration in NT compared to CT, this has not yet been clearly demonstrated, while an increase of infiltration rate has been reported with NT, resulting in a reduction of the water runoff and soil erosion. It is known that the erosion rate depends on soil type, topography, climate,

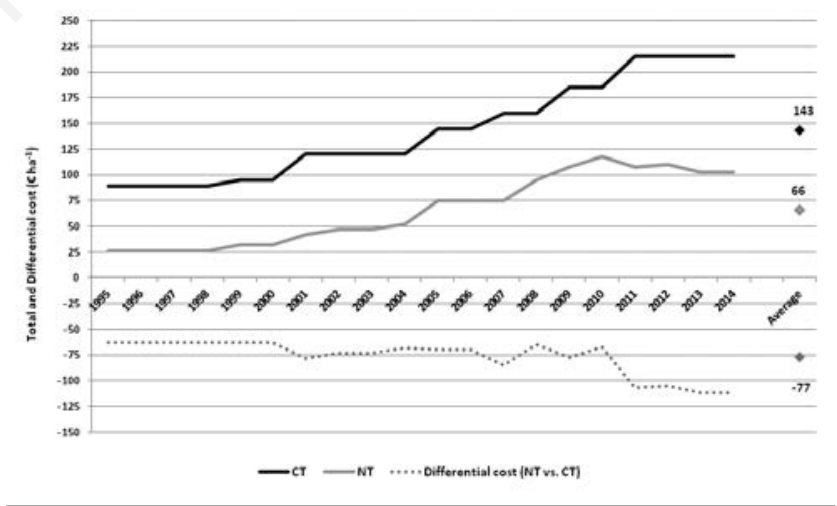

Figure 5. Trend of total and differential costs for no-tillage (NT) and conventional tillage (CT) systems during 1995-2014. Data were collected at the Cereal Research Centre-Council for Agricultural Research and Economics of Foggia.

Table 1. Carbon costs of the variables that occur in the conservation and the conventional systems.

\begin{tabular}{ll} 
Variables & CA ws conventional agriculture \\
Fuel consumption per unit area per unit output & $35-80 \%$ less \\
Number of passes & $50-54 \%$ less \\
\hline Size of machinery & $50 \%$ lower power requirement \\
Depreciation rate of machinery & $2-3$ times lower (i.e., 2-3 times longer lifetime)
\end{tabular}

Source: Food and Agriculture Organization of the United Nations, 2012, Corsi S, Friedrich T, Kassam A, Pisante M, de Moraes Sà JC, Soil organic carbon accumulation and greenhouse gas emission reductions from conservation agriculture: a literature review, integrated crop management, http://www.fao.org/ag/ca/CA-Publications/WEBBOOK_16_CARBON_LR.pdf. Reproduced with permission. CA, conservation agriculture. 
and rainfall duration and intensity, but several studies have shown signification reductions with CA practices compared to conventional practices in a range of conditions at field scale (Meijer et al., 2013; Montgomery, 2007; Zhang et al., 2007), at water-shed/catchment scales (Prasuhn, 2012) and with climate change simulations (Zhang, 2012). Runoff and erosion are typically reduced by an order of magnitude with NT compared to conventional (Kay et al., 2009; Prasuhn, 2012).

Compared to conventional management, the practices used in CA increase the plant water availability due to increased water infiltration and reduced evaporation, as a result of the surface soil undisturbed and residues covering the ground that decrease soil evaporation (Rinaldi $e t$ al., 2000).

Troccoli et al. (2009b) at CREA-CER carried out a field trial on a monoculture of durum wheat comparing CT and NT systems. At the $14^{\text {th }}$ year of experiment they assessed the soil moisture with gravimetric method during the 2009 growing season at four soil depths and from April to June and reported an average moisture content of the soil significantly higher in NT (13\% dry mass basis) than in CT (10\%) management (Figure 6), equivalent to about $22 \mathrm{~mm}$ of water saving. The interaction date $x$ management resulted highly significant, having NT average values of soil moisture always higher than the CT management. Only the interaction date $x$ management $x$ depth was found to be not significant. The moisture content found higher in NT than in CT soil may be the most likely explanation of the higher yields recorded in NT when drought dominates the growing seasons.

\section{Greenhouse gases emission}

Residues management and crop rotations can affect $\mathrm{N}_{2} \mathrm{O}$ emissions by altering the availability of $\mathrm{NO}_{3}{ }^{-}$in the soil, the decay rates of $\mathrm{C}$ substrates (Firestone and Davidson, 1989). The retention of crop residues and higher soil $\mathrm{C}$ in surface soils with CA play major roles in these processes. Under anaerobic conditions associated with soil water saturation, high contents of soluble carbon or readily decomposable organic matter can significantly boost denitrification (Dalal et al., 2003) with the production of $\mathrm{N}_{2} \mathrm{O}$ favoured with high quality $\mathrm{C}$ inputs. The quantity and quality of residues or cover crops of CA systems can also affect $\mathrm{N}_{2} \mathrm{O}$ emissions. Legume residues can result in higher $\mathrm{N}_{2} \mathrm{O}-\mathrm{N}$ losses (Baggs et al., 2000; Huang et al., 2004; Millar et al., 2004) than those from nonlegume, low $\mathrm{N}$ residues.

With NT, residues are returned to the soil resulting in surface mulches, which may lower evaporation rates and hence increase soil moisture and increase labile organic carbon C (Galbally et al., 2005) and consequently increase $\mathrm{N}_{2} \mathrm{O}$ emissions compared to CT. On the other hand, lower soil temperatures and better soil structure under NT may reduce the incidence of soil saturation and reduce emissions of $\mathrm{N}_{2} \mathrm{O}$. Rochette's (2008) extensive summary concluded that NT only increased $\mathrm{N}_{2} \mathrm{O}$ emissions in poorly aerated soils. Ussiri et al. (2009) found for a long-term continuous corn that the average daily fluxes and annual $\mathrm{N}_{2} \mathrm{O}$ emissions were more in MT $\left(0.67 \mathrm{mg} \mathrm{m}^{-2} \mathrm{~d}^{-1}\right.$ and $1.82 \mathrm{~kg} \mathrm{~N}$ ha $^{-1}$ year-1) and CT ( $0.74 \mathrm{mg} \mathrm{m}^{-2} \mathrm{~d}^{-1}$ and $1.96 \mathrm{~kg} \mathrm{~N} \mathrm{ha}^{-1}$ year-1) than NT $\left(0.29 \mathrm{mg} \mathrm{m}^{-2} \mathrm{~d}^{-1}\right.$ and $0.94 \mathrm{~kg} \mathrm{~N} \mathrm{ha}^{-1}$ year-1). Lower $\mathrm{N}_{2} \mathrm{O}$ emission and increased $\mathrm{CH}_{4}$ oxidation in the NT practice are attributed to decrease in surface soil bulk density, suggesting increased gaseous exchange. The $\mathrm{N}_{2} \mathrm{O}$ flux was strongly correlated with precipitation, air and soil temperatures, but not with gravimetric moisture content. Data from Ussiri et al. (2009) suggested that adoption of long-term NT under continuous corn cropping system in the U.S. Corn Belt region might reduce global warning potential associated with $\mathrm{N}_{2} \mathrm{O}$ and $\mathrm{CH}_{4}$ emissions by approximately $50 \%$ compared to MT and CT management.

The effect of tillage practices on the rate of $\mathrm{CH}_{4}$ consumption, in general, depends on the changes in gas diffusion characteristics in soil (Hutsch, 1998; Gregorich et al., 2006). A decrease in $\mathrm{CH}_{4}$ consumption and a potential net emission of $\mathrm{CH}_{4}$ could be expected with RT or NT due to increased bulk density and water-filled pore space.

\section{Carbon sequestration}

The world's soils are estimated to contain $1500 \mathrm{Gt}$ of soil organic carbon (SOC), roughly double the amount of $\mathrm{C}$ in the atmosphere (Schlesinger, 2000), while in the world's oceans the contain of $\mathrm{C}$ is esti-

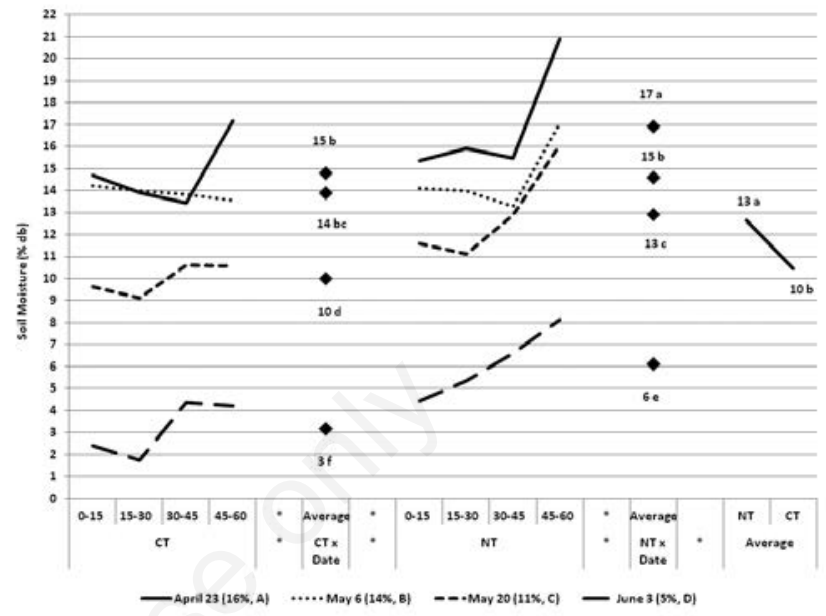

Figure 6. Trend of soil moisture for a monoculture of durum wheat grown in no-tillage (NT) and conventional tillage (CT) systems. The soil sampling were performed during the 2009 growing season at four soil depths and from April to June at the Cereal Research Centre-Council for Agricultural Research and Economics (Foggia). For sampling date, management and interaction date $x$ management, respectively, capital and lowercase letters indicate that mean values are different at the $\mathrm{P}=5 \%$ according to Tukey's honestly significant difference test (from Troccoli et al., 2009a).

Table 2. Farming operation costs for conventional and no-tillage systems collected at the Cereal Research Centre-Council for Agricultural Research and Economics of Foggia during 19952014. The costs refer to the prices charged by the local farm subcontractors. The values are twenty-year period averages.

\begin{tabular}{lcc} 
Farming operations & $\begin{array}{c}\text { CT } \\
\left(€ \mathrm{ha}^{-1}\right)\end{array}$ & $\begin{array}{c}\text { NT } \\
\left(€ \mathrm{ha}^{-1}\right)\end{array}$ \\
Mouldboard plowing & 68.00 & - \\
Disk plow & 25.10 & - \\
\hline Disk plow & 25.10 & - \\
Chemical weed control & - & 13.30 \\
Sowing & 25.10 & 53.00 \\
\hline Total & 143.30 & 66.30 \\
Differential cost (NT-CT) & - & -77.00 \\
\hline Economic benefit (\%) & - & 53.7
\end{tabular}

CT, conventional tillage; $\mathrm{NT}$, no-tillage.

Table 3. Range of average prices (2014) in Italy of conventional and direct cereal of $3 \mathrm{~m}$ width seeders.

\begin{tabular}{lc} 
Seed drill kind & Price $(€)$ \\
Mechanical & $3000-5000$ \\
Pneumatic & $5000-8000$ \\
\hline Direct driller & $10,000-20,000$ \\
\hline
\end{tabular}


mated in 38,000 Gt. Although the main cause of increased $\mathrm{CO}_{2}$ in the atmosphere has been the fossil fuel combustion, a significant contribution was also provided by land modifications. Reicosky (2002) attributed to the soil plowing the main blame for this loss of $\mathrm{C}$, and these soils are viewed as a depleted $\mathrm{C}$ reservoir that can be refilled by appropriate management. It has been argued that if conservation tillage practices were adopted in all cultivated land for a period of 50 years, it would have as main result the sequestration of $25 \mathrm{Gt} \mathrm{C}$, marking this overall strategy as the key tool for the stabilisation of atmospheric $\mathrm{CO}_{2}$ concentrations (Pacala and Socola, 2004).

However, Grandy et al. (2006) indicated that with even a single tillage event, sequestered soil carbon and years of soil restoration may be lost, and that the damage to the soil life was usually greater than the loss of soil carbon. In general, in tilled soils the mixing of the litter favours bacteria (hence quick degradation processes), while the higher presence of fungi in NT systems (Beare et al., 1992; Drijber et al., 2000) is responsible for a build-up of soil carbon in the form of polymers of melanin and chitin which are relatively stable and resistant to degradation (Stahl et al., 1999; Bailey et al., 2002). The mouldboard plough disturbs the greatest soil volume and produces the maximum $\mathrm{CO}_{2}$ flux, while NT causes the least amount of $\mathrm{CO}_{2}$ loss, with the amount of $\mathrm{CO}_{2}$ loss being directly correlated to the disturbed soil volume (Reicosky and Lindstrom, 1993; Reicosky, 1998). Some authors found negative SOC storage rates under repeated monocropping in NT systems (Carter and Kunelius, 1986; VandenBygaart et al., 2003).

Different rotations have different potential to promote and support carbon sequestration and some authors reported negative SOC accu- mulation rates under CA mainly associated with specific rotations, i.e. barley - wheat - soybean rotation (Angers et al., 1997), maize - wheat soybean (VandenBygaart et al., 2003); on the contrary, when a greenmanure crop with high annual above-ground biomass production is included in the crop rotation the carbon stocks are positive and signif-

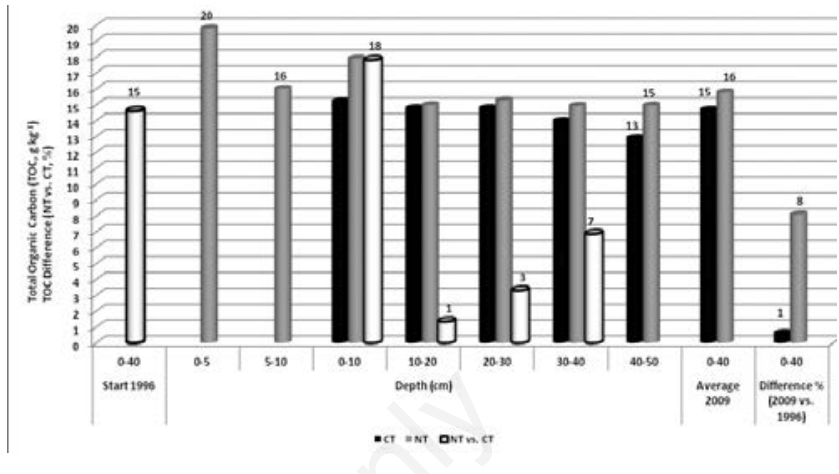

Figure 7. Trend along soil profile of total organic carbon (TOC) values for no-tillage (NT) and conventional tillage (CT) systems. Soil samples were collected in the October 2009 at the Cereal Research Centre-Council for Agricultural Research and Economics of Foggia after 14 years from start of the experiment (from Troccoli et al., 2009a).

Table 4. Synopsis of the effects of conservation agriculture adoption and their justification of a subsidy to the farmers.

\begin{tabular}{|c|c|c|c|}
\hline Aspects & Effects & Need of an economical support & $\begin{array}{l}\text { Economic support non } \\
\text { necessary or at stakeholder's } \\
\text { discretion }\end{array}$ \\
\hline Agronomic & $\begin{array}{l}\text { Reduction of crop yield levels } \\
\text { (as function of soil fertility and } \\
\text { quality especially during transition period) } \\
\text { Soil fertility improvement } \\
\text { (organic matter, structure, microbial activity) } \\
\text { consequential }\end{array}$ & $\begin{array}{l}\text { In general, a decreasing subsidy of about } 100-75-50 \\
€ / \mathrm{ha}^{-1} \text { during the first } 3 \text { years of transition to CA }\end{array}$ & $\begin{array}{l}\text { It represents an advantage } \\
\text { to CA adoption }\end{array}$ \\
\hline Economic & $\begin{array}{l}\text { Lower production costs } \\
\text { (reduced tillage and complementary } \\
\text { operations) } \\
\text { New machinery investments } \\
\text { (single or joint farms with at least } 50 \text { ha size) } \\
\text { Subsidy to small farms for renting } \\
\text { the direct seeders ( }<50 \text { ha) }\end{array}$ & $\begin{array}{l}\text { To promote the CA is necessary } \\
\text { to purchase direct seeder and machines } \\
\text { or crop residues management } \\
\text { The rent cost of a direct seeder can range } \\
\text { from } 80 \text { to } 120 € / \mathrm{ha}^{-1}\end{array}$ & $\begin{array}{l}\text { The money saving can be quantified in } \\
120-150 € / \mathrm{ha}^{-1} \text { in flat, } 200-250 € / \mathrm{ha}^{-1} \text { in } \\
\text { hilly and } 300-400 € / \mathrm{ha}^{-1} \text { in mountain } \\
\text { conditions }\end{array}$ \\
\hline Environmental & $\begin{array}{l}\text { Lower soil erosion } \\
\text { (a more efficient soil cover with crop } \\
\text { residues and/or cover crop; additional } \\
\text { costs for cover crops establishment) } \\
\text { Greater water infiltration } \\
\text { (due to crop residues and cover crop, } \\
\text { at root canals and pedofauna) } \\
\text { Reduced GHG emissions } \\
\text { (reduced fuel consumption and soil } \\
\text { organic matter oxidation) } \\
\mathrm{CO}_{2} \text { sequestration }\end{array}$ & $\begin{array}{l}\text { Soil erosion risk increase with slope } \\
\text { (from } 1 \text { to } 10 \text { t ha }^{-1} \text { year }^{-1} \text { ) } \\
\text { A financial support to compensate } \\
\text { additional costs should be in the } 50-100 € / \mathrm{ha}^{-1} \text { range } \\
\text { as function of orography }\end{array}$ & $\begin{array}{l}\text { Reduction of landslide risk and, for this, } \\
\text { a money saving for environmental protection } \\
\text { by hydrogeological instability } \\
\text { As a function of soil quality and sloping } \\
\text { from } 35 \text { to } 65 \mathrm{~kg}^{-} \mathrm{C} \mathrm{ha}^{-1} \mathrm{year}^{-1} \\
\text { Greater microbial activity in the shallow } \\
\text { soil layer }(5-10 \mathrm{~cm})\end{array}$ \\
\hline
\end{tabular}

$\mathrm{CA}$, conservation agriculture; $\mathrm{GHG}$, greenhouse gases; $\mathrm{C}$, carbon; $\mathrm{CO}_{2}$, carbon dioxide. 
icantly greater (Diekow et al., 2005). Also the availability of sufficient plant residue is often a limit to the amount of carbon accumulated in the soil. In fact, mixing readily decomposable carbon (e.g., residues with low $\mathrm{C} / \mathrm{N}$ ratio, or liquid manure) in the presence of stable SOM generally induces a priming effect and increases $\mathrm{CO}_{2}$ emissions; in contrast, the composition of crop residues not mixed into the soil does not affect the decay of the SOM present (Chadwick et al., 1998; Fontaine, 2007). When the soil is not tilled for many years, SOM decomposition in soil surface layers is reduced and causes the active fractions of SOM to increase (Franzluebbers et al., 1995; Horá ek et al., 2001). Consequently in NT soils the degree of SOC stratification (i.e., the stratification ratio) can be used as an indicator of soil quality. Another indicator to assess the influence of management on functional processes in soils (such as decomposition and nutrient cycling) is soil enzyme activity (Dick, 1994; Dilly et al., 2003). For a more complete discussion on the issue read the review of Corsi et al. (2012).

According to the finding reported by Franzluebbers and Arshad (1996) that reported from little to no detectable increase in SOC in the first 2-5 years, but a large increase 5-10 years after switching to $\mathrm{CA}$, also West and Post (2002) found that soil $\mathrm{C}$ sequestration was generally increased by no-tillage practices, but had a delayed response, with peaks in years 5-10. Sá et al. (2001) estimated that in comparison with the native field a significant increase in storage SOC occurred with long-term no-tillage (20-22 years) and more than $60 \%$ of this increase was stratified in the first $10 \mathrm{~cm}$ of soil. During in the first 10 years of no-tillage the SOC gain was positive only the top 5-cm layer while the second ten years the rate of $\mathrm{C}$ sequestration was positive for all depths (up to $40-\mathrm{cm}$ ) being $80.6 \mathrm{~g} \mathrm{C} \mathrm{m}^{-2}$ year-1 for 0 - to $20-\mathrm{cm}^{-1} 99.4 \mathrm{~g} \mathrm{C} \mathrm{m}^{-}$ 2 year-1 for 0 - to $40-\mathrm{cm}$ depth. Compared to SOC pool of the native field, for 0 - to $20-\mathrm{cm}$ the SOC balance was $+16.94 \mathrm{Mg} \mathrm{ha}^{-1}$ for NT (22 years) and $-1.26 \mathrm{Mg} \mathrm{ha}^{-1}$ for CT (22 years) systems.

Our data support the aforementioned results (Troccoli et al., 2009a). After 14 years, although the TOC difference was about only 1\% between NT (15.8 $\left.\mathrm{g} \mathrm{kg}^{-1}\right)$ and CT (14.7 $\left.\mathrm{g} \mathrm{kg}^{-1}\right)$ systems, the NT system sequestered a greater amount of $\mathrm{C}(+8.1 \%)$ than the CT $(+0.6 \%)$ system (Figure 7$)$. In addition, the top soil layer $(0-5 \mathrm{~cm})$ of NT had a very high value of TOC (19.8 $\left.\mathrm{g} \mathrm{kg}^{-1}\right)$, which dropped to $16 \mathrm{~g} \mathrm{~kg}^{-1}$ in the next soil layer $(5-10 \mathrm{~cm})$. Comparing the different soil layers, the values of TOC for NT system were the following: $17.8 \%, 1.4 \%, 3.3 \%$, and $6.9 \%$ higher than the CT system, at the depths of $0-10,10-20,20-30$ and 30 $40 \mathrm{~cm}$, respectively.

\section{Conclusions}

Agri-environmental measures are key elements for the integration of environmental concerns into the Common Agricultural Policy. They are designed to encourage farmers to protect and enhance the environment on their farmland by paying them for the provision of environmental services. Agri-environment measures may be designed at the national, regional, or local level so that they can be adapted to particular farming systems and specific environmental conditions. This makes agri-environmental measures a targeted tool for achieving environmental goals.

The effort that has been done up to now, with regard to the actual impact of CA on several agri-environmental aspects, it was helpful to open a working table in order to know the main markers that can justify a community support for a more generalised sharing and extension of the CA. In Table 4 these findings are summarised, although the complexity of the processes involved (soil, climate, cropping systems, company size, the dynamics of prices and costs, the economic evaluation of the environmental aspects) does not allow a simple and definite economic computation.

In conclusion, for the expansion of the $\mathrm{CA}$ in Italian conditions we consider necessary and a priority to encourage, on the one hand, the purchase of specific equipment, and, secondly, to support with ad hoc measures (a kind of re-nature bonus) the farmers that decide to adopt the conservative management to improve the agro-ecological system as well as the environmental sustainability.

Therefore, the public incentive for the adoption of conservation agriculture should only be considered as a decisive support for the task undertaken by farmers to protect the environment. In Italy, a first step in this direction was made by several Regional Local Governments which have proposed financial support in the Piani di Sviluppo Rurale (Rural Development Programs) for the agri-climate-environmental measures, from 135 to $400 € \mathrm{ha}^{-1}$, roughly differentiated as a function of soil productivity, if use minimum or strip or no tillage systems, with or without cover crops.

In this proposal we suggest to differentiate the financial support between small and big farmers according to the farm size (threshold about $50 \mathrm{ha}$ ): i) small farmers: $150-200 € \mathrm{ha}^{-1}$; if several small farmers join together in a cooperative in order to have a farm size greater than 50 ha, this association can have the same advantages of big farmers; ii) big farmers: $100-150 € \mathrm{ha}^{-1}$ plus a financial support for the machinery purchase (i.e., $50 \%$ free and $50 \%$ capital grant of final price).

For areas characterised by particular vulnerability (high erosion, nutrient leaching or desertification risk), an environmental subsidy extra could be added $\left(100-200 € \mathrm{ha}^{-1}\right)$.

This economical subsidy to farmers could be gradually reduced when knowledge and acceptance of these practices will become ordinary. Finally, in order to best support the farmers about seeding, weed control, fertilisation, residues management and cover crops, a technical support to the farmers should be also considered.

\section{References}

Angers DA, Bolinder MA, Carter MR, Gregorich EG, Drury CF, Liang BC, Voroney RP, Simard RR, Donald RG, Beyaert RP, Martel J, 1997. Impact of tillage practices on organic carbon and nitrogen storage in cool, humid soils of eastern Canada. Soil Till. Res. 41:191-201.

Baggs EM, Rees RM, Smith KA, Vinten AJA, 2000. Nitrous oxide emission from soils after incorporating crop residues. Soil Use Manage. 16:82-7.

Bailey VL, Smith JL, Bolton HJ, 2002. Fungal-to-bacterial ratios in soils investigated for enhanced carbon sequestration. Soil Biol. Biochem. 34:1385-9.

Beare MH, Parmelee RW, Hendrix PF, Cheng W, Coleman DC, Crolley DA Jr, 1992. Microbial and faunal interactions and effects on litter nitrogen and decomposition in agroecosystems. Ecol. Monogr. 62:569-91.

Bignell DE, Tondoh J, Pin Huang S, Moreira F, Nwaga D, Pashanasi B, Guimares Pereira E, Susilo FX, Swift MJ, 2005. Below-ground biodiversity assessment: developing a key functional group approach in best-bet alternatives to slashand burn. In: Palm CA, Vosti SA, Sanchez PA, Ericksen PJ (eds.), Slash-and-burn agriculture: the search for alternatives. Columbia University Press, New York, NY, USA, pp 488.

Bissett A, Richardson AE, Baker G, Kirkegaard J, Thrall PH, 2013. Bacterial community response to tillage and nutrient additions in a long-term wheat cropping experiment. Soil Biol. Biochem. 58:281-92.

Blevins RL, Smith MS, Thomas GW, Frye WW, Cornelius PL, 1983. Changes in soil properties after 10 years continuous non-tilled and conventionally tilled corn. Soil Till. Res. 3:135-46.

Brussaard L, 2012. Ecosystem services provided by the soil biota. In: Wall DH, Bardgett RD, Behan-Pelletier V, Herrick JE, Hefin Jones T, Ritz K, Six J, Strong DR, van der Putten WH (eds.), Soil and ecology and 
ecosystems services. Oxford University Press, Oxford, UK, pp 45-58.

Bueno J, Amiama C, Hernanz JL, Pereira JM, 2006. Penetration resistance, soil water content, and workability of grassland soils under two tillage systems. Trans. ASAE 49:875-82.

Carter MR, 1988. Penetration resistance to characterise the depth and persistence of loosening in tillage studies. Can. J. Soil Sci. 68:657-68.

Carter MR, Kunelius HT, 1986. Comparison of tillage and direct drilling for Italian ryegrass on the properties of a fine sandy loam soil. Can. J. Soil Sci. Manitoba 66:197-207.

Chadwick DR, van der Weerden T, Martinez J, Pain BF, 1998. Nitrogen transformations and losses following pig slurry applications to a natural soil filter system (Solepur process) in Britany, France. J. Agr. Eng. Res. 69:85-93.

Chen Y, Monero FV, Lobb D, Tessier S, Cavers C, 2004. Effects of six tillage methods on residue incorporation and crop performance in a heavy clay soil. Trans. ASABE 47:1003-10.

Chen Y, Tessier S, 1997. Techniques to diagnose plow and disk pans. Can. Agric. Engine. 39:143-7.

Colecchia SA, Rinaldi M, De Vita P, 2015. Effects of tillage systems in durum wheat under rainfed Mediterranean conditions. Cereal Res. Commun. 2015;43:4.

Corsi S, Friedrich T, Kassam A, Pisante M, de Moraes Sà JC, 2012. Soil organic carbon accumulation and greenhouse gas emission reductions from conservation agriculture: a literature review, integrated crop management. Vol. 16. AGP/FA0, Rome, Italy. Available from: http://www.fao.org/ag/ca/CA-Publications/WEB-B00K_16_CARBON_LR.pdf

Dalal RC, Wang W, Robertson GP, Parton WJ, 2003. Nitrous oxide emissionfrom Australian agricultural lands and mitigation options, a review. Aust. J. Soil Res. 41:165-95.

Dick RP, 1994. Soil enzyme activities as indicators of soil quality. In: Doran JW, Coleman DC, Bezdicek DF, Stewart BA (eds.), Defining soil quality for a sustainable environment. Soil Science Society of America, Madison, USA, pp 107-124.

Diekow TJ, Mielniczuk J, Knicker H, Bayer C, Dick DP, Kögel-Knabner I, 2005. Soil C and N stocks as affected by cropping systems and nitrogen fertilisation in a southern Brazil Acrisol managed under notillage for 17 years. Soil Till. Res. 81:87-95.

Dilly 0, Blume HP, Munch JC, 2003. Soil microbial activities in Luvisols and Anthrosols during 9 years of region-typical tillage and fertilisation practices in northern Germany. Biogeochemistry 65:319-39.

Derpsch R, Franzluebbers AJ, Duiker SW, Reicosky DC, Koeller K, Friedrich T, Sturny, WG, Sá JCM, Weiss K, 2014. Why do we need to standardise no-tillage research. Soil Till. Res. 137:16-22.

De Vita P, Di Paolo E, Fecondo G, Di Fonzo N, Pisante M, 2007. No-tillage and conventional tillage effects on durum wheat yield, grain quality and soil moisture content in southern Italy. Soil Till. Res. 92:69-78.

Doan V, Chen Y, Irvine B, 2005. Effect of residue type on the performance of no-till seeder openers. Can. Biosyst. Engine. 47:229-35.

Drijber RA, Doran JW, Parkhurst AM, Lyon DJ, 2000. Changes in soil microbial community structure with tillage under long-term wheatfallow management. Soil Biol. Biochem. 32:1419-30.

FA0, 2001. World Soil Resources Reports 96: Soil carbon sequestration for improved land management. Food and Agriculture Organisation (FA0), Rome, Italy.

FAO, 2011. What is conservation agriculture? FAO Food and Agriculture Organisation (FA0), Rome, Italy. Available from: http:/www.fao.org/ag/ca/la.html

FAO, 2015. Conservation agriculture adoption worldwide. Food and Agriculture Organisation (FA0), Rome, Italy. Available from:

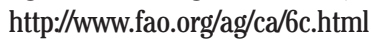

Firestone MK, Davidson EA, 1989. Microbiological basis of NO and $\mathrm{N}_{2} \mathrm{O}$ production and consumption in soils. In: Andreae MO, Schimel DS (eds.), Exchanges of trace gases between terrestrial ecosystems and the atmosphere. John Wiley \& Sons, New York, NY, USA.

Fontaine S, 2007. Stability of organic carbon in deep soil layers controlled by fresh carbon supply. Nature 450:277-80.

Fornasier F, Russo M, Troccoli A, Farina R, 2012. No tillage increased soil organic carbon and biological activity in a Mediterranean vertisol in Apulia, Italy. Abstract of the $4^{\text {th }}$ International Congress of the ECSSS - European Confederation of Soil Science Societies - Session S07.07 Long-term effects of agronomic practices on soil organic matter and crop productivity. Bari, Italy, 2-6 July 2012, p 1803 [presentation of a poster: P-28].

Franzen H, Lal R, Ehlers W, 1994. Tillage and mulching effects on physical properties of a tropical Alfisol. Soil Till. Res. 28:329-46.

Franzluebbers AJ, Arshad MA, 1996. Soil organic matter pools during early adoption of conservation tillage in northwestern Canada. Soil Sci. Soc. Am. J. 60:1422-7.

Franzluebbers AJ, Hons FM, Zuberer DA, 1995. Tillage and crop effects on seasonal soil carbon and nitrogen dynamics. Soil Sci. Soc. Am. J. 59:1618-24.

Galbally I, Meyer M, Bently S, Weeks I, Leuning R, Kelly K, Phillips F, Barker-Reid F, Gates W, Baigent R, Eckard R, Grace P, 2005. A study of environmental and management drivers of non-CO2 greenhouse gas emissions in Australian agro-ecosystems. In: Van Amstel E.A. (Ed.), Non-C02 Green-house gases: science, control, policy and implementation: Proc. 4th Int. Symp. on Non-C02 Greenhouse Gases. Millpress, pp 47-55.

Gantzer CJ, Blacke GR, 1978. Physical characteristics of le Sueur clay loam soil following no-till and conventional tillage. Agron. J. 70:853-7.

Genro Jr SA, 2002. Soil compaction alteration by use of crop rotation in notillage system. MSc Dissertation, Santa Maria, Universidade Federal de Santa Maria, 90 pp. [in Portuguese with English abstract].

Gregorich EG, Rochette P, Hopkins DW, McKim UF, St-Georges P, 2006. Tillage-induced environmental conditions in soil and substrate limitation determinebiogenic gas production. Soil Biol. Biochem. 38:2614-28.

Griffith DR, Mannering JV, Moldehauer WC, 1977. Conservation tillage in the eastern Corn Belt. J. Soil Conserv. 32:20-8.

Håkansson I, 2005. Machinery-induced compaction of arable soils. Reports from the Division of Soil Management, Uppsala, no. 109, 153 pp.

Horá ek J, Ledvina R, Raus A, 2001. The content of quality of organic matter in cambisol in a long-term no tillage system. Rostlinná Výroba 47:205-10.

Horn R, 2004. Time dependence of soil mechanical properties and pore functions for arable soils. Soil Sci. Soc. Am. J. 68:1131-7.

Huang Y, Zou J, Zheng X, Wang Y, Xu X, 2004. Nitrous oxide emissions as influenced by amendment of plant residues with different $\mathrm{C}: \mathrm{N}$ ratios. Soil Bio. Biochem. 36:973-81.

Hutsch BW, 1998. Tillage and land use effects on methane oxidation rates and their vertical profiles in soil. Biol. Fert. Soils 27:284-92.

Kacemi M, Hilali H, Monroe G, 1992. Effect of different tillage methods on bulk density, penetrability and aggregate size distribution on a clay soil. Homm. Terre Aux 86:96-102.

Kay P, Edwards AC, Foulger M, 2009. A review of the efficacy of contemporary agricultural stewardship measures for ameliorating water pollution problems of key concern to the UK water industry. Agr. Syst. 99:67-75.

Landers JN, 2008. Environmental impacts and social dimensions of zerotillage conservation agriculture in tropical Brazil. In: Goddard T, Zoebisch MA, Gan TY, Ellis W, Watson A, Sombatpanit S (eds.) No-till farming systems. Special publication n. 3. World Association of Soil and Water Conservation, Bangkok, pp 103-135.

Meijer AD, Heitman JL, White JG, Austin RE, 2013. Measuring erosion in long-term tillage plots using ground-based lidar. Soil Till. Res. 126:1-10. 
Millar N, Ndufa JK, Cadisch G, Baggs EM, 2004. Nitrous oxide emissions fol-lowing incorporation of improved- fallow residues in the humid tropics. Global Biogeochem. Cycles 18:GB1032.

Montgomery DR, 2007. Soil erosion and agricultural sustainability. Proc. Natl. Acad. Sci. U. S. A. 104:13268-72.

Morris NL, Miller PCH, Orson JH, Froud-Williams RJ, 2010. The adoption of non-inversion tillage systems in the United Kingdom and the agronomic impact on soil, crops and the environment. A review. Soil Till. Res. 108:1-15.

Pacala S, Socola R, 2004. Stabilisation wedges: solving the climate problem for the next 50 years with current technologies. Science 365:96872.

Palm C, Blanco-Canqui H, DeClerck F, Gatere L, Grace P, 2014. Conservation agriculture and ecosystem services: An overview. Agric. Ecosyst. Environ. 187:87-105.

Pisante M, 2008. Agricoltura Blu. La via Italiana dell'agricoltura conservativa. Principi, tecnologie e metodi per una produzione sostenibile. Il Sole 24 Ore-Edagricole Editore, Bologna, Italy, XII+317 pp.

Pittelkow C, Liang X, Linquist BA, van Groenigen KJ, Lee J, Lundy ME, van Gestel N, Six J, Venterea RT, van Kessel C, 2015. Productivity limits and potentials of the principles of conservation agriculture. Nature 517:365-8.

Prasuhn V,2012. On-farm effects of tillage and crops on soil erosion measured after10 years in Switzerland. Soil Till. Res. 120:137-46.

Reichert JM, Reinert DJ, Braida JA, 2003. Soil quality and sustainability of agrosystems. Ci. Ambiente 27:29-48 [in Portuguese with English abstract].

Reichert JM, Suzuki LEAS, Reinert DJ, Horn R, Håkansson I, 2009. Reference bulk density and critical degree-of-compactness for no-till crop production in subtropical highly weathered soils. Soil Till. Res. 102:242-54.

Reicosky DC, 1998. Effect of tillage on the release of $\mathrm{CO}_{2}$. Paper presented to the Symposium "Conservation Tillage: Can it assist in mitigating the Greenhouse Gas Problem?", The University of Queensland, Australia.

Reicosky DC, 2002. Long-term effect of moldboard plowing on tillageinduced C02 loss. In: Kimble JM, Lal R (eds.), Agricultural practices and policies for carbon sequestration in soil. CRC Press Inc., Boca Raton, FL, USA, pp 87-97.

Reicosky DC, Lindstrom MJ, 1993. Fall tillage methods: effect on shortterm carbon dioxide flux from soil. Agron J 85-6:1237-43.

Rinaldi M, Rana G, Introna M, 2000. Effects of partial cover of durum wheat straw on soil evaporation in a semi-arid region. Acta Hortic. 537:159-65.

Rochette $\mathrm{P}, 2008$. No-till only increases $\mathrm{N}_{2} \mathrm{O}$ emissions in poorly-aerated soils. Soil Till. Res. 101:97-100.

Ruisi P, Giambalvo D, Saia S, Di Miceli G, Frenda AS, Plaia A, Amato G, 2014. Conservation tillage in a semiarid Mediterranean environment: results of 20 years of research. Ital. J. Agron. 9:560.

Sá JCM, Cerri CC, Dick WA, Lal R, Filho SPV, Piccolo MC, Feigl BE, 2001. Carbon sequestration in a plowed and no-tillage chronosequence in a Brazilian Oxisol. In: Stott DE, Mohtar RH, Steinhardt GC (eds.), Sustaining the global farm. Purdue University and USDA-ARS National Soil Erosion Research Laboratory, Washington, DC, USA, pp 466-471.

Schlesinger WH, 2000. Soil respiration and the global carbon cycle. Biogeochemistry 48:7-20.

Scopel E, Triomphe B, Affholder F, Da Silva FAM, Corbeels M, Xavier JHV,
Lahmar R, Recous S, Bernoux M, Blanchart E, de Carvalho Mendes I, De Tourdonnet S, 2012. Conservation agriculture cropping systems in temperate and tropical conditions, performances and impacts. A review. Agron. Sustain. Develop. 2015 [In press].

Singh P, Sharratt B, Schillinger WF, 2012. Wind erosion and PM10 emission affected by tillage systems in the world's driest rainfed wheat region. Soil Till. Res. 124:219-25.

Soil Survey Staff, 1999. Soil taxonomy - Agricultural handbook 436. Washington, DC, USA, pp 869.

Stahl PD, Parkin TB, Christensen M, 1999. Fungal presence in paired cultivated and uncultivated soils in central Iowa, USA. Biol. Fertil. Soils 29:92-7.

Tekeste MZ, Raper RL, Schwab E, 2008. Soil drying effects on soil strength and depth of hardpan layers as determined from cone index data. Agric. Engine. Int. CIGR Ej. X:17.

Troccoli A, Colecchia SA, Cattivelli L, Gallo A, 2009a. Risposta quali-quantitativa di una monocoltura di frumento duro coltivato al Sud in regime prolungato di non lavorazione del suolo. Atti del XXXVIII Convegno Nazionale della Società Italiana di Agronomia, Sessione I Tecniche Agronomiche, Firenze, 21-23 settembre 2009, pp 23-24 [presentazione orale].

Troccoli A, Colecchia SA, Gallo A, 2007. Effetto della semina su sodo sugli aspetti quali-quantitativi della produzione di frumento duro coltivato in monosuccesione a Foggia. In: Pisante M (ed.), Agricoltura Blu. La via Italiana dell'agricoltura conservativa. Principi, tecnologie e metodi per una produzione sostenibile. Il Sole 24 Ore-Edagricole Editore, Bologna, Italy, pp 87-88.

Troccoli A, Colecchia SA, Russo M, Cattivelli L, Gallo A, 2009b. Agricoltura conservativa ideale per il grano duro al Sud. Inf. Agrario 34:37-41.

Troccoli A, Gallo A, Ficco A, Nicastro G, De Gregorio V, Selvaggio V, Padalino A, Russo, M, 2014. Lavorazioni del terreno e agricoltura conservativa. Notiziario regionale di Agricoltura integrata - Regione Basilicata, Vol. 1, 8:3-8. Available from: http//www.cerealresearchcentre.it/main/images/stories/pdf/78)\%202014_Notiziario\%20ALSIA_LAv orazioni\%20del\%20terreno\%20e\%20agricoltura\%20conservativa.pdf

Ussiri DAN, Lal R, Jarecki MK, 2009. Nitrous oxide and methane emissions from long-term tillage under a continuous corn cropping system in Ohio. Soil Till. Res. 104:247-55.

Van de Putte A, Govers G, Diels J, Gillijns K, Demuzere M, 2010. Assessing the effect of soil tillage on crop growth: a meta-regression analysis on European crop yields under conservation agriculture. Eur. J. Agron. 33:231-41.

VandenBygaart AJ, Yang XM, Kay BD, Aspinall JD, 2002. Variability in carbon sequestration potential in no-till soil landscapes of southern Ontario. Soil Till. Res. 65:231-41.

Verhulst N, Govaerts B, Verachtert E, Mezzalama M, Wall PC, Chocobar A, Deckers J, Sayre KD, 2010. Conservation agriculture, improving soil quality for sustainable production systems? In: Lal R, Stewart BA (eds.), Advances in Soil Science: Food Security and Soil Quality. CRC Press, Boca Raton, FL, USA, pp 137-208.

West T0, Post WM, 2002. Soil organic carbon sequestration rates by tillage and crop rotation: a global data analysis. Soil Sci. Soc. Am. J. 66:1930-46.

Zhang SL, Simelton E, Lovdahl L, Grip H, Chen DL, 2007. Simulated longterm effects of different soil management regimes on the water balance in the LoessPlateau. China. Field Crop. Res. 100:311-9.

Zhang XC, 2012. Cropping and tillage system effects on soil erosion under climate change in Oklahoma. Soil Sci. Soc. Am. J. 76:1789-97. 